\title{
DETERMINISME TEKNOLOGI KOMUNIKASI DAN TUTUPNYA MEDIA SOSIAL PATH
}

\author{
Ajeng Iva Dwi Febriana \\ Program Studi Ilmu Komunikasi, Universitas Jayabaya Jakarta \\ email: febrianaiva04@gmail.com
}

\begin{abstract}
The focus of this research is the influence of communication technology on the existence of social media. Determinism of technology makes humans as objects of technology itself which shapes humans both in terms of thinking, opinion and acting in a society. As a new media, online media and social media are required to continuously present the speed of information and make the audience able to easily interact with anyone and with anything. The novelty of features and the speed of information in social media (social networking) become a benchmark for the existence of social media. The closure of Path's social media services because social media cannot meet the needs of its users and the lack of new features in the application so that users are limited in accessing what information will be consumed and the loss of private space for social media users Path makes Path slowly begin abandoned by its users because it is considered to have no advantage anymore.
\end{abstract}

Keywords: Determinism of Technology, Existence, Social Media

\section{PENDAHULUAN}

Perkembangan teknologi komunikasi dan informasi membawa perubahan besar pada media massa. Ditandai dengan bermunculannya media baru berupa media online dan media sosial. Media baru tersebut menawarkan kecepatan informasi nyaris tanpa batas ruang dan waktu, kebebasan berpendapat, komunikasi antar khalayak yang begitu komplek yang membuat khalayak menjadi begitu mudah terhubung satu sama lain. Kehadiran media baru ini sekaligus perlahan-lahan menggeser pola komunikasi antar khalayak yang awalnya komunikasi dilakukan secara tatap muka, saat ini komunikasi dilakukan secara virtual melalui media online dan media sosial.

Melalui media sosial khalayak bebas menentukan pilihan informasi apa yang akan dikonsumsinya, bebas memilih dengan siapa mereka akan berinteraksi, bebas memilih apa yang akan mereka bagikan. Berbeda dengan media lama yang pola komunikasinya hanya searah dan tidak adanya interaksi langsung, khalayak cenderung pasif dalam menerima informasi dan tidak memiliki pilihan informasi yang dibutuhkan sesuai keinginannya.

Seiring perkembangan tersebut perlahan tapi pasti media-media lama mulai ditinggalkan khlayak dan mereka berpindah ke media baru yaitu media online termasuk media sosial yang merupakan bagian dari media baru yang menawarkan kecepatan akses informasi. Hal ini ditandai dengan banyaknya media cetak lama yang menutup kegiatan operasionalnya sehingga menimbulkan istilah era "senjakala media lama". Beberapa tahun terakhir sejumlah media cetak memutuskan untuk tidak melanjutkan produksi koran mereka lagi. Sebut saja Sinar Harapan yang tutup pada tahun 1 Januari 2016, disusul kemudian dengan Jakarta Globe, Koran Sindo, Majalah Femina, Tabloid Soccer, Harian Bola, Indonesia Finance Today, Majalah Chip, Majalah TRAX, Harian Jurnal Merdeka, Majalah Remaja Cosmo Girl, Tablid Remaja Gaul dan sederat media cetak lainnya. Jika diperhatikan media cetak yang tutup adalah media cetak 'senior" yang sudah puluhan tahun berada di industri bisnis media, namun pada akhirnya mereka menyerah juga ketika digitalisasi mulai memasuki industri media cetak. Mereka tidak bisa nolak pun tidak bisa marah dengan arus globalisasi dan kemajuan teknologi yang berkembang semakin pesat dan dinamis.

Namun, tidak semua media cetak tutup total ada juga yang kemudian mengalihkan bisnis media cetak mereka ke bentuk digital contohnya majalah remaja HAI yang sejak Juni 2017 memutuskan untuk mengalihkan majalah yang telah terbit sejak tahun 1977 tersebut ke dalam bentuk digital yang bisa di akses dalam laman hai.grid.id, perubahan ini 
memang mengikuti perkembangan jaman, secara fisik menjadi lebih mudah diakses dalam bentuk digital sekaligus menyesuaikan selera pasar saat ini yaitu generasi millenial yang menjadi pembaca terbanyak majalah HAI. Selain majalah HAI ada juga Koran Tempo, Intisari yang bertransformasi ke dunia digital. Mau tidak mau, suka tidak suka pemilik media dipaksa mengikuti arus zaman. Digitalisasi media adalah hal yang tidak bisa ditolak maupun dihalangi. Mereka dihadapkan pada dua pilihan. Mengikuti perkembangan teknologi atau tertinggal.

Media online dan media sosial di tuntut untuk terus menghadirkan informasi yang dibutuhkan khalayak secara cepat dan terus menerus mengupdate informasinya dalam segala hal. Kemajuan teknologi membuat khlayak ingin mendapatkan informasi terus menerus dan bisa terhubung dengan siapapun dengan mudah. Ketika media sosial tidak mampu memenuhi keinginan khalayak maka ia akan ditinggalkan oleh penggunanya seperti yang terjadi pada media sosial Path yang per 18 Oktober 2018 resmi menutup layanannya.

\section{METODE PENELITIAN}

Dalam menyusun penelitian ini metode penelitian yang digunakan adalah deskrptif kualitatif. Metode penelitian deskriptif kualitatif bertujuan untuk mengungkapkan suatu kejadian, fakta, keadaan , fenomena, variabel yang tengah terjadi. Penelitian ini menguraikan data, sikap, serta pandangan yang terjadi di dalam suatu masyarakat, pertentangan antara dua keadaan atau lebih, hubungan antar variabel yang timbul, perbedaan antar fakta melalui studi pustaka diantaranya jurnal, buku dan referensi lainnya yang digunakan dalam penelitian ini.

\section{MEDIA SOSIAL}

Di era yang serba instan dan cepat ini, kehadiran media baru sangat membantu konektifitas khalayak baik dari segi kecepatan maupun kemudahan akses informasi. Kapanpun dan dimanapun dan dengan siapapun khalayak bisa dengan mudah mengakses informasi yang dibutuhkan tanpa adanya batasan ruang dan waktu. Era android saat ini membuat layar telepon selular pun diramaikan dengan lahirnya media-media sosial seperti Facebook, Twitter, Instagram, Path, Line, Snapchat dan masih banyak lagi. Fenomena ini menggambarkan bahwa khalayak membutuhkan tempat yang mempu membuat mereka selalu terhubung dengan siapa saja dan apa saja karena sifatnya yang kompleks bahkan media sosial mampu menembus batas status sosial yang selama ini menjadi salah satu penghalang komunikasi.

Media sosial adalah media yang terkoneksi tidak hanya pada satu platform saja, tetapi pada banyak platform yang membuat kita bisa berkomunikasi langsung dengan banyak orang dalam waktu yang bersamaan dalam bentuk chatting ataupun pengiriman email (Fuchs, 2017:6).

Sementara Van Dijk mendefinisikan media sosial adalah platform media yang memfokuskan pada eksistensi pengguna yang memfasilitasi mereka dalam beraktivitas maupun berkolaborasi. Karena itu media sosial dapat dilihat sebagai medium (fasilitator) online yang menguatkan hubungan antar pengguna sekaligus sebagai ikatan sosial (Fuchs dalam Nasrullah, 2015:11).

Meike dan Young mengartikan sosial media sebagai konvergensi antara komunikasi personal dalam arti saling berbagi di antara individu (to be shared one-to-one) dan media publik untuk berbagi kepada siapa saja tanpa ada kekhususan individu (Nasrullah, 2015:11). Pada intinya, dengan sosial media dapat dilakukan berbagai aktifitas dua arah dalam berbagai bentuk tulisan, visual maupun audiovisual. Sosial media diawali dari tiga hal, yaitu Sharing, Collaborating dan Connecting (Puntoadi, 2011:5).

Sebagai media baru, tentunya media sosial memiliki karakteristik yaitu:

1. Jaringan (Network) antar pengguna Kata "jaringan (network) bisa dipahami dalam terminologi bidang teknologi seperti ilmu komputer yang berarti insfrastruktur yang menghubungkan antara komputer maupun perangkat keras (hardware) lainnya. Koneksi ini diperlukan karena komunikasi bisa terjadi jika antarkomputer terhubung, termasuk di dalamnya perpindahan data (Castells, 2002; Gane\&Beer, 2008 dalam Nasrullah, 2015:16).

Karakter media sosial adalah membentuk jaringan di antara penggunanya. Tidak perduli apakah di dunia nyata (offline) antar pengguna itu saling kenal atau tidak, namun kehadiran media sosial memberikan 
medium bagi pengguna untuk terhubung secara mekanisme teknologi. (Nasrullah, 2015:16-17).

2. Informasi (Informations)

Informasi menjadi entitas penting di media sosial karena pengguna media sosial mengkreasikan representasi identitasnya, memproduksi konten dan melakukan interkasi berdasarkan informasi

3. Arsip (Archive)

Bagi pengguna media sosial, arsip menjadi sebuah karakter yang menjelaskan bahwa informasi terlah tersimpan dan bisa diakses kapanpun dan melalui perangkat apapun.

4. Interaksi (Interactivity)

Media sosial membentuk jaringan antar pengguna yang tidak sekedar memperluas hubungan pertemanan atau pengikut (follower) semata, tapi harus dibangun dengan interaksi antar pengguna tersebut.

5. Simulasi Sosial (Simulation of Society)

Media sosial memiliki karakter sebagai medium berlangsungnya masyarakat (society) di dunia virtual. Media sosial memiliki keunikan dan pola yang dalam banyak kasus berbeda dan tidak dijumpai dalam tatanan masyarakat yang real.

6. Konten oleh Pengguna (UserGenerated Content).

Di media sosial konten sepenuhnya milik dan berdasarkan kontribusi pengguna atau pemilik akun. UGC merupakan relasi simbiosis dalam budaya media baru yang memberikan kesempatan dan keleluasaan pengguna untuk berpartisipasi. Hal ini berbeda dengan media lama (tradisonal) dimana khlayaknya sebatas menjadi objek atau sasaran yang pasif dalam distribusi pesan. (Nasrullah, 2015:1631).

Selain memiliki karakteristik, media sosial juga terdiri dari beberapa jenis, yaitu:

1. Media Jejaring Sosial (Social Networking)

Media sosial merupakan medium yang paling populer. Media ini merupakan sarana yang bisa digunakan pengguna untuk melakukan hubungan sosial, termasuk konsekuensi atau efek dari hubungan sosial tersebut di dunia virtual. Karakter utama dari situs jejaring sosial adalah setiap pengguna membentuk jaringan pertemanan, bakik terhadap pengguna yang sudah diketahuinya dan kemungkinan saling bertemu di dunia nyata (offline) mampu membentuk jaringan pertemanan baru.

2. Jurnal Online (Blog)

Blog merupakan media sosial yang memungkinkan penggunanya untuk menggugah aktifitas keseharian, saling mengomentari dan berbagi, baik tautan web lain, informasi dan sebagainya. Pada awalnya blog merupakan suatu bentuk situs pribadi yang berisi kumpulan tautan ke situs lain yang dianggap menarik dan diperbarui setiap ahrinya. Pada perkembangan selanjutnya, blog banyak jurnal (tulisan keseharian pribadi) ppemilik media dan terdapat kolom komentar yang bisa diisi oleh pengguna. Secara mekanis, jenis media sosial ini bisa dibagi menjadi dua, yaitu kategori personal homepage, yaitu pemilik menggunakan nama domain sendiri seperti .com atau net dan yang kedua dengan weblog gratis, seperti wordpress atau blog spot.

3. Jurnal Online sederhana atau microblog (Micro-blogging)

Tidak berbeda dengan jurnal online (blog), microblogging merupakan jenis media sosial yang memfasilitasi pengguna untuk menulis atau mempublikasikan aktifitas atau pendapatnya. Contoh microblogging yang paling banyak digunakan adalah Twitter.

4. Media berbagi (media sharing)

Situs berbagi media merupakan jenis media sosial yang memfasilitasi penggunanya untuk berbagi media, mulai dari dokumen (file), video, audio, gambar dan sebagainya. Contohnya adalah Youtube, Flickr, Photo-bucket.

5. Penanda Sosial (social bookmarking) Penanda sosial merupakan media sosial yang bekerja untuk mengorganisasi, menyimpan, mengelola dan mencari informasi 
untuk berita tertentu secara online. Beberapa situs sosial bookmarking yang populer adalah delicious.com, stumbleUpon.com, Digg.com, Reddit.com, dan untuk di Indonesia ada LintasMe.

6. Media konten bersama atau Wiki

Media sosial ini merupakan situs yang kontennya hasil kolaborasi dari para penggunanya. Mirip dengan kamus atau ensiklopedia, wiki menghadirkan kepada pengguna pengertian, sejarah hingga rujukan buku atau tautan tentang satu kata. Dalam prakteknya, penjelasan-penjelasan tersebut dikerjakan oleh pengunjung, artinya ada kolaborasi atau kerja sama dari semua pengunjung untuk mengisi konten dalam situs ini. (Nasrullah, 2015:40-46).

Salah satu media sosial yang memiliki banyak pengguna adalah Path. Jejaring sosial Path didirikan pertama kali pada 2010 lalu di San Fransisco, Amerika Serikat oleh tiga serangkai. Mereka adalah Dave Morin, Shawn Fanning dan Dustin Mierau (Kompas.com, 1809-2018) Aplikasi ini mulai beroperasi sejak tahun 2010, media sosial yang memiliki simbol berwarna merah tersebut adalah media sosial yang pertama kali menghadirkan sebuah perbedaan dibandingkan dengan media sosial yang lebih dulu ada seperti Facebook dan Twitter.

Sebagai media sosial bisa dikatakan Path memiliki karakteristik yang unik dibanding media sosial lainnya. Ketika Facebook sebagai media sosial menghadirkan ruang publik yang begitu luas dan bebas justru Path malah membatasi ruang publik tersebut dan lebih mengutamakan ruang private dengan cara membatasi jumlah kuota pertemanan pengguna akun Path, yaitu hanya 150 orang saja yang bisa berteman antar pemilik akun. Saking privatenya, khalayak tidak bisa melihat profile pengguna Path yang lain jika belum berteman dan meski telah berteman sesama pengguna Path pun jika kita ingin melihat profile pengguna yang lain maka akan muncul pemberitahuan bahwa akun pribadi pengguna telah dilihat oleh pengguna Path yang lain.

Path juga memberikan fitur yang berbeda dibanding sosial media lainnya. Ketika Facebook\&Twitter memiliki fitur komenntar dan like, Path menghadirkan fitur Senyum, Tertawa, Terkejut, Sedih dan Love sebagai bentuk reaksi atau respon terhadap unggahan pemilik akun. Selain itu Path juga memiliki fitur Check In yang menunjukkan bahwa pengguna tengah berada di suatu tempat dengan teman atau keluarga. Fitur yang tidak kalah menariknya adalah di aplikasi ini kita bisa memberi tahu aktifitas yang tengah dilakukan hanya dengan mengklik fitur status yang berisi pilihan kita tengah mendengarkan musik, membaca buku dan menonton film. Selain berbagi foto ataupun video Path ini juga memiliki fitur sticker comment yang bisa diunduh secara gratis maupun berbayar dengan tema yang berbeda-beda.

Untuk melindungi privasi penggunanya, path menyediakan fitur pilihan status yang artinya kita bisa membagikan unggahan untuk orang yang berteman dengan kita atau hanya orangorang terdekat saja yang bisa melihat unggahan kita. Ketika media sosial kebanyakan memberikan ruang publik yang begitu bebas dan luas, Path hadir memberikan pilihan yang berbeda dengan keamanan akun pengguna yang lebih terjamin dan tetap bisa terintegrasi dengan sosial media Facebook, Twitter, Tumblr, Foursquare. Path pun selalu update memberikan informasi ulang tahun dari teman sesama pengguna, informasi tentang tempat kuliner, tempat wisata dll.

Karena kehadirannya yang lebih private dibanding dengan media sosial lainnya maka tidak heran banyak khalayak yang memilih Path sebagai aplikasi media sosial favorit. Banyaknya kasus kriminal yang terjadi melalui Facebook seperti penipuan, pembunuhan membuat pengguna media sosial menjadi lebih hati-hati dalam memilih dan menggunakan media sosial dan Path mampu memenuhi keinginan khalayak tersebut.

Melihat keunikan sekaligus kelebihan pada media sosial Path, mendorong Facebook menghadirkan fitur keamanan yang sama dalam aplikasinya, yaitu menghadirkan juga ruang private dimana pemilik akun sudah bisa memilih siapa yang dapat melihat unggahannya, fitur yang awalnya hanya ada Like juga ditambahkan dengan simbol Like, Love, Tertawa, Terkejut, Sedih dan Kaget. Demikian juga halnya dengan aktifitas yang tengah dilakukan oleh penggunanya, Facebook menghadirkan fitur mendengarkan musik, menonton film, memasak, membaca buku persis seperti yang terdapat pada aplikasi Path. Hal ini dilakukan oleh Facebook karena menyadari sebagian besar penggunanya 
beralih ke media sosial Path dengan alasan keamanan dan private. Dengan memperbaharui aplikasinya Facebook ingin agar penggunanya kembali aktif menggunakan Facebook.

Dapat dikatakan bahwa Path adalah pendatang baru di ranah jejaring sosial namun berhasil meraih popularitas dalam waktu yang relatif singkat. Hal ini menggambarkan bahwa Path berhasil menarik minat khalayak di seluruh dunia hingga mencapai 10 juta orang pengguna dan pengguna terbesar adalah dari Indonesia yaitu berjumlah 5 juta pengguna Path.

Semua media sosial selalu memperbaharui fitur-fitur yang terdapat di aplikasinya, seperti Facebook yang mulanya hanya menampilkan fitur like\&comment di kolom status, beberapa tahun yang lalu Facebook mulai menampilkan fitur yang sama dengan Path, yaitu respon Like, Love, Sedih, Terkejut dan Marah. Selain mengadopsi fitur reaksi di status milik Path, Facebook juga mengadopsi fitur "What Are You Doing" yang berisikan aktivitas yang akan dipilih oleh pengguna seperti membaca, menonton film, tidur, masak ataupun ketika traveling.

Karena lebih bersifat personal, maka penggunanya bisa dengan mudah mendapatkan informasi tentang orang-orang terdekat yang saling berteman antar pengguna Path, seperti tengah berada dimana, apa yang tengah dilakukan dan dengan siapa. Hal tersebut juga membuat individu yang memiliki akun di Facebook, Twitter dan Path melakukan unggahan status yang berbeda baik itu di Facebook, Twitter maupun di Path ddengan alasan status di Facebook dan Twitter boleh dilihat oleh semua orang sementara unggahan di Path hanya boleh diketahui oleh orangorang terdekat saja demi menjamin kerahasiaan.

\section{DETERMINISME TEKNOLOGI PADA MEDIA SOSIAL PATH}

Kemajuan teknologi telah membuat perubahan pada diri manusia karena teknologi membentuk diri manusia, dimana mereka berfikir, bersikap dalam suatu masyarakat atau menentukan pilihan berdasarkan teknologi yang mempengaruhinya.

Teori Determinisme Teknologi pertama kali dikemukakan oleh Marshall McLuhan di tahun 1962 melalui tulisannya yang berjudul The Guttenberg Galaxy: The Making of
Typographic Man dengan pokok gagasan dari teori ini adalah bahwa pola kehidupan masyarakat manusia, khususnya aspek interaksi sosial diantara mereka, ditentukan oleh perkembangan dan jenis teknologi yang dikonsumsi oleh masyarakat itu sendiri (McLuhan. 1994:108).

McLuhan berpendapat bahwa media merupakan faktor utama yang paling memperngaruhi hal lainnya. Secara umum, teori determinisme teknologi ini berusaha menjelaskan bagaimana sebuah teknologi terutama media sangat berpengaruh dalam menentukan bagaimana individu dalam masyarakat memikirkan, merasakan dan melakukan suatu tindakan tertentu.

Dasar pemikirannya adalah perubahanperubahan cara manusia untuk berkomunikasi membentuk keberadaan kita dan sebagai budayawan ia berpendapat bahwa budaya itu terbentuk berdasarkan bagaimana kemampuan kita untuk berkomunikasi. Untuk memahami pernyataan di atas, teori ini mempunyai tiga kerangka urutan pemikiran, yaitu:

1) Penemuan-penemuan hal baru dalam bidang teknologi komunikasi menyebabkan perubahan budaya

2) Perubahan komunikasi manusia membentuk eksistensi kehidupan manusia

3) "We shape outr tools, and they in turn shape us". McLuhan. (Kita membentuk alat-alat yang kita perlukan dan sekarang giliran alat-alat itu yang membentuk diri kita) (Saefudin, 2008:384)

Atas tiga kerangka urutan pemikiran tersebut McLuhan menyatakan bahwa media merupakan inti dari peradaban manusia. Dominasi media dalam sebuah masyarakat menentukan dasar organisasi sosial manusia dan kehidupan kolektifnya (Saefudin, 2008:384).

Teori determinisme teknologi semakin berkembang seiring dengan perkembangan teknologi komunikasi yang sangat berpengaruh terhadap perkembangan media massa juga interaksi sosial antar sesama manusia dengan ditemukan dan masuknya internet dalam kehidupan sehari-hari. Internet mengubah dunia sekaligus manusia. Pesatnya perkembangan teknologi komunikasi melahirkan media baru atau media sosial sebagai media interaktif yang menggunakan 
jaringan internet membuat seluruh belahan dunia terhubung dengan mudah.

Lebih luas diungkapkan bahwa media baru yang muncul akibat inovasi teknologi dalam bidang media meliputi televisi kabel, satellites, teknologi optic fiber dan komputer. Dengan teknologi seperti ini, pengguna bisa secara interaktif membuat pilihan serta menyediakan respon produk media secara beragam (Croteau, 1997:12).

Determinisme teknologi berawal dari asumsi bahwa teknologi adalah kekuatan kunci dalam mengatur masyarakat. Dalam paham ini struktur sosial dianggap sebagai kondisi yang terbentuk oleh materialistic teknologi. Lain halnya dengan analisis Feenberg yang mengemukakan dua premis determinisme teknologi yang bermasalah. Pertama, teknologi berkembang secara unlinear dari konfigurasi sederhana kearah yang lebih kompleks. Kedua, masyarakat harus tunduk pada perubahanperubahan yang terjadi dalam dunia teknologi itu (Smith dalam Saefullah, 2007:28).

Jika dikaitkan dengan tutupnya media sosial Path, maka dapat di paparkan bahwa teknologi membentuk manusia bagaimana ia berfikir, bersikap dan menentukan pilihannya dan kehadiran media baru ini semakin membuat koneksi antar manusia menjadi lebih mudah terhubung dalam berinteraksi sekaligus mendapatkan informasi yang dibutuhkannya karena manusia adalah objek dari teknologi itu sendiri. Sebagai media sosial Path dianggap tidak mampu memberikan perubahan yang dibutuhkan oleh pengguna mengingat teknologi terus berkembang dan berperan dalam mengendalikan khalayak pengguna media sosial.

Sebagai media sosial yang digandrungi oleh kawula muda yang selalu haus akan perubahan-perubahan teknologi juga informasi, seharusnya Path mampu mengikuti arus perkembangan media sosial yang dituntut harus selalu mampu memenuhi apa yang menjadi keinginan penggunanya. Path harus bergerak cepat dalam melakukan perubahanperubahan terhadap fitur-fitur aplikasinya mengingat individu penggunanya sangat dipengaruhi oleh kemajuan teknologi. Ketika media sosial lain memiliki fitur terkini yang membuat koneksi menjadi semakin luas dan semakin mendapatkan apa yang diinginkan dengan mudah, Path tidak melakukan perubahan, padahal Path adalah media sosial yang pertama menghadirkan ruang private bagi para penggunanya.

Media sosial lain menghadirkan fitur yang memberikan keuntungan bagi pengguna, justru Path lebih banyak melakukan perubahan hanya pada fitur stiker sebagai simbol interaksi antar pengguna Path. Meski perubahan ini menjadi nilai lebih, namun lama kelamaan pengguna Path menjadi bosan untuk menggunakan media sosial ini, ditambah lagi dengan diakuisisinya saham Path oleh Daum Kakao, perusahaan asal Korea Selatan yang melakukan perubahan jumlah pertemanan di Path yang awalnya hanya berjumlah 150 orang menjadi 500 orang membuat mengingkari sendiri konsep awal media sosial yang memiliki simbol berwarna merah tersebut.Path tidak lagi menjadi media sosial yang dipilih karena tersedianya ruang private. padahal saat itu hal ini yang membuat pengguna Facebook dan Twitter beralih menuju Path karena Path dianggap lebih bersifat personal karena penggunanya bebas berbagi dan menyampaikan apa saja tanpa khawatir akan diketahui dan dibaca oleh orang lain sebab dengan terbatasnya kuota pertemanan maka hanya orang-orang terdekat saja yang dapat melihat unggahan tersebut. Seringkali pemilik akun Facebook, Twitter, Instagram dan Path menuliskan unggahan dan status yang berbeda-beda baik di Facebook, Twitter, Instagram dan Path dengan alasan keamanan dan privatisasi. Mereka melakukan unggahan berupa status, foto dll disesuaikan dengan karakter teman dan interaksi mereka yang ada di media sosial tersebut.

Akibat yang ditimbulkan dengan tidak adanya perubahan dalam fitur aplikasinya membuat penggunanya merasa bosan karena tidak adanya pembaruan dan bersifat statis. Berbeda dengan yang dilakukan Instagram, menyadari bahwa keinginan individu penggunanya adalah memiliki jaringan yang luas dalam segala hal Instagram lebih jeli dalam melihat perubahan ini, maka Instagram menghadirkan fitur-fitur baru mengikuti perkembangan teknologi yaitu fitur Insta Story dan Video Live. Komunikasi yang terjalin antar khalayak pengguna Instagram menjadi lebih kompleks karena mudah sekali terhubung oleh apapun dan siapapun. Saat ini Instagram banyak digunakan untuk aktifitas bisnis online sehingga melahirkan tren baru yaitu Selebgram atau Selebriti Instagram. Tren saat ini di Instagram adalah pemilik bisnis online mengendorse 
selebgram untuk mempromosikan produknya agar menarik minat beli nitizen. Keuntungan pun didapat oleh kedua pihak tersebut.

Menyadari keaktifan penggunanya menurun jauh, Path sempat melakukan pembaruan fitur yaitu unggahan video dan eksplorasi dimana pengguna bisa mengetahui unggahan dan aktifitas pengguna Path yang lain meski tidak saling mengenal dan berteman. Pembaruan ini telah lebih dahulu dimiliki oleh Instagram. Saat Path melakukan pembaruan-pembaruan fitur, penggunanya sudah terlanjur beralih ke Instagram dan perlahan tapi pasti Path mulai ditinggalkan oleh penggunanya karena dianggap sudah tidak memiliki keunggulan lagi.

Karena sepinya peminat dan semakin jarangnya pengguna Path menggunakan aplikasinya, akhirnya Path mengeluarkan pernyataan resmi melalui Path.com/about bahwa jejaring sosialnya tidak akan menyediakan layanannya kepada pengguna Path alias tutup. Kabar ini pun diperkuat dengan post yang berjudul "The Last Goodbye" yang mewarnai halaman beranda aplikasi Path sebagai penanda bahwa jejaring sosial yang pernah digandrungi anak muda tersebut tidak dapat lagi di update pada 18 Oktober 2018 dan pada 15 November 2018 Path resmi tutup.

\section{KESIMPULAN}

Tergambar jelas bahwa individu manusia adalah objek dari teknologi itu sendiri dan media merupakan salah satu alat yang digunakan untuk menyebarkan teknologi. Media jenis apapun harus bergerak cepat mengikuti perkembangan teknologi demi memenuhi keinginan khalayak dan teknologi sangat mempengaruhi pola konsumsi khalayak terhadap media.

\section{REFERENSI}

BUKU

Croteau, David \& Hoynes, William. (1997).

Media Society: Industries, Images and Audiences. PineForge Press. London.

Fusch, Christian. (2017). Social Media: A Critical Introduction 2nd Edition. SAGE Publication Ltd. California.
Media sosial sebagai media baru menawarkan kecepatan dan kebaruan informasi, interaksi sosial yang lebih kompleks. Sebenarnya kebaruan-kebaruan dalam fitur media sosial timbul karena adanya interaksi antara individu yang satu dengan yang lainnya, ini yang membedakan media lama dan media baru. Interaksi antar individu menjadi sangat kompleks.

Media dalam bentuk apapun merupakan alat untuk memperluas dan memperkuat pengaruhnya dalam pemikiran dan tindakan manusia. Dengan kata lain, masing-masing penemuan teknologi media baru yang betulbetul dipertimbangkan untuk memperluas dan kecakapan manusia (Surahman, 2016:33).

Ketika media sosial tidak mampu mengimbangi derasnya arus perubahan teknologi yang menyebabkan interaksi antar individu menjadi terbatas serta minimnya informasi yang di dapat maka media sosial harus bersiap diri untuk menanggung kerugian karena ditinggalkan oleh penggunanya seperti yang dialami oleh Path. Media sosial yang memiliki pengguna sebanyak 10 juta orang di seluruh dunia dengan pengguna terbesar di Indonesia yaitu 5 juta orang akhirnya harus menyerah pada teknologi layaknya media lama yang tidak mampu mengikuti perkembangan teknologi.

Sebebas apapun ruang debat, ruang publik yang dihadirkan oleh media sosial saat ini, individu pengguna sosial media tetap membutuhkan ruang private demi keamanan mereka sendiri. Meski media sosial menciptkan kebebasan berpendapat dan berkespresi tetapi semuanya tetap dibatasi oleh ruang private.

McLuhan, Marshall. (1994). Understanding Media: The Extension of Man. London. The MIT Press.

Nasrullah, Rulli. (2015). Media Sosial; Perspektif Komunikasi, Budaya dan Sosioteknologi.Simbiosa Rekatama Media. Bandung. 
Puntoadi, Danis. (2011). Menciptakan Jualan Melalui Sosial Media. Elex Media Komputindo. Jakarta.

\section{JURNAL ILMIAH}

Saefudin, Asep. (2008). Perkembangan Teknologi Komunikasi: Perspektif Komunikasi Peradaban. Jurnal Mediator Volume 9 No.2

Surahman, Sigit. (2016). Determinisme Teknologi Komunikasi Dan Globalisasi
Media Terhadap Seni Budaya Indonesia. Jurnal Rekam Vo. 12 No. 1 April.

\section{SUMBER LAIN}

https://tekno.kompas.com/read/2018/09/18/12 044197/salah-langkah-dan-ingkari-konsepalasan-path-tak-lagi-berkembang tanggal akses 27 September 2018. 